\title{
Analyzing Media Dependency During Crises. A case of COVID-19 in Malaysia
}

\author{
Faiswal Kasirye* \\ Department of Communication \\ International Islamic University Malaysia \\ kasirye.faiswal@gmail.com
}

\section{INTRODUCTION}

World over, it is a well-known fact that media are a vital factor that shapes our society for the better. It is one way of exposing the public to a multitude of information through both digital and traditional media. In fact, in some circumstances, the availability of such information may be based on to determine who are better-informed citizens depending on how they conduct themselves in society.

In times of crisis like the current COVID-19, digital and traditional media play an important role in informing the public on the developments regarding the pandemic and how to avoid being contacted by it. For example, at the onset of the outbreak of the virus, the government of Malaysia in conjunction with the World health organization (WHO) relayed a multitude of information related to the virus through television and radio stations as well as the many available digital platforms in the country. In addition, several online news websites were also not left out because, in times such as these, the public is struggling to get credible information relating to the crisis and therefore would be looking in every corner for it and hence, both mass media and the internet do a very important job in making known what is not.

Furthermore, in all crises around the world, the media is always credited for maintaining stability especially concerning relaying relevant and credible information to the public. the major reason here is because the public is always in trust of the media and is always waiting to hear from what the media is to relay to them at all times. This information will help them make critical decisions after consuming such information as laid down by Mitomo et al. (2012). In addition, Longstaff (2005) believes that the media becomes a key element for the functioning of the society because usually, the public tends to give more attention and trust to the media instead of the state to understand the environment in which they live. the author adds that in managing abrupt crises, trustworthy and reliable information is pivotal to social resilience. 
Also, in crises like the pandemic, there is usually unusual demand for information and sensemaking of the information circulating in the media by those who understand it. That's why media dependency theory postulates that the media is always perceived to best know how to satisfy the public's information needs and wants because they offer credible and structured information. Scholars of media dependency conclude that "it is the structural dependency on the media for signals, interpretation, and information about bad times and other potentially threatening situations that determines the intensified dependency of people in crises" (Ball-Rokeach, 1985, p.498).

When one talks about the public's dependency on the media, what usually comes to our minds is the traditional sources which are newspapers, television, and radio stations as the official media platforms where the public is expected to get official information from all relevant authorities. However, the $19^{\text {th }}$ and $20^{\text {th }}$ centuries have emerged with new technologies that are now shaping information flow that has changed the entire management of the media substantially. However, Napoli (2015) believes that although the two media systems are different, they have the same responsibilities to uphold to the public.

In light of the above, the existence of both the digital and traditional media creates a need to understand how the public depends on them for information and what makes them choose what they choose to get information from during a crisis like the current COVID-19 pestilence. This will be done by exploring the facets of the media dependency theory. Which predicts that "in crises, people's dependency on media tends to be heightened" (Ball-Rokeach, 1985, p. 495).

This study is therefore set out to understand how the public informed themselves about the COVID-19 crisis in Malaysia by highlighting how they depended on the media to get information regarding the same as well as its importance in getting the information. Furthermore, to dive more into the issue of media dependency in disasters and crises, previous studies are regarding the same are reviews in the subsequent section.

\section{Media Systems Dependence Theory (MSD)}

The media systems dependency theory that is adopted as the theoretical framework for this study was invented by Ball-Rokeach and DeFleur (1976) to understand how the public relates to the media. Ball- Rokeach (1998) defines media dependency as "a theory about the determinants and 
the consequences of this dependency relations: its formation; variation across individual, time, and situation; and its consequences" (p.17).

The main assumptions of the theory as according to Khalifa and Khalifa (2020) include;

"the degree of stability of the social system and its general balance varies as a result of continuous changes, and according to this difference, the need for information and news increases and decreases."

"The social structure of the media (access to information, ease of use, etc.) has an effect on the motives for looking for information, as the degree of dependence on the media system prevailing in society increases in the case of a few other media channels and reliance on it decreases in the case of alternative channels for news and information."

"People differ in the degree of their dependence on the media as a result of their disagreement on the goals they seek to achieve, whether they are personal or social, and the individual interests and needs related to obtaining information. These goals and needs are linked to demographic variables (gender, age, education, socioeconomic level, in determining the strength of dependence on the media."

"the possibility of achieving the media message of cognitive, emotional, and behavioral influences increases when media systems provide diverse information services, and the effect increases in cases of conflict and crises"

"The more media-dependent individuals are, the more likely they will persuade and increase their interaction with others" (p. 331)

The theory, in general, contends that when the public starts to depend on the media be it mass media or the current emergent new media to gratify their needs, the media then becomes their primary source of information that they consume Li (2014). Therefore, relationships develop between the public and the media because the media presents the public with opportunities to understand their environments with news and information relating to a particular subject of interest to the public (Grant, \& Meadows, 2020). The scholars intimate that "media dependency is not a one-way process but rather, both the public, the media, and the social system depend on each other. 
Ball-Rokeach and DeFleur (1976) initially argue that the extent to which the public relies on media as a source of information is a central point in appreciating how it influences the public's behavior. Beliefs and feelings. The scholars assume that, when the public becomes complex or encounters complex issues, the media comes in with a very important role in streamlining issues and make them have a sense of understanding of the issues at hand.

The theory has often been applied to crises and disaster studies especially in situations where the public is most likely to have difficulty in making important decisions because the situations tend to escalate beyond their understanding. Consequently, the public's reliance on the media tends to increase, specifically if they notice that it is the only available source of information (BallRokeach, 1985).

The theory also considers the power of demographic variables and other related social features on the same level as though they have a huge influence on an individual's dependency on the media of their choice. Accordingly, the theory dons that, a person's status such as "power and their class" indirectly influences their dependency on media (Ball-Rokeach, 1985). For example, people with higher economic statuses have higher chances of accessing knowledge and information from any source be it government, which makes them depend more on other sources than the media. Furthermore, the above Ball-Rokeach'z revelation confirms Loges's (1994) study where he notes that individuals with high levels of education rarely prefer traditional media or any media for news or information because they have other sources where they can get the same information or even more.

Lowery (2004) mentions that demographic characteristics like age and gender contribute a lot to how an individual consumes information from the media. The scholar argues that younger information or news consumers are more deepened on the media than the older ones especially in the current digital space that is surrounded by the youths. Further, gender has also been found out to be a predictor of time spent online, where, male respondents were found to be reading online news more than their female counterparts (Patwardhan \& Yang, 2003).

Since the invention of the theory in the 1970s, the theory has been used to guide dependence studies that focus on the relationship between the media, social system, the public, and mass media. however, the advancement of technology has brought about numerous other types that require the testing of the theory to understand the news media's effects of media dependency (Li, 2014). 


\section{Media Dependence in Crises}

In times of crises, the media becomes the major source of information for the public, since their job becomes one of informing the public of what is happening in their environment because they need to know and protect themselves and their decisions. Scholars have previously done some studies on media dependency in times of crises where they mainly refer to media as the main traditional media outlets like the radio, television, and newspapers although, in some instances, various scholars have added digital platforms as sources of the media where people tend to get information for their personal use and decision making during disasters and crises (Tai \& Sun, 2007 and Lowrey, 2004).

Furthermore, Lowrey (2004) believes that understanding the media is more specious during situations of crisis because the public becomes more intrigued to know whatever is happening and why it is happening. However, Ball-Rokeach (1985) argues that someone's dependency on the media cannot be reduced to just the goals and aims they want but rather, the goals are the most important aspects of people's inspiration and fundamental media system dependencies.

The theory its self predicts that people's dependency on the media tends to always increase during times of disasters and crises as according to Ball-Rokeach (1985). Various studies regarding dependency on terrorism (Lowrey, 2004), N1H1 outbreak (Hu \& Zhang, 2014), China earthquakes (Jiang \& Ouyang, 2008) have all concluded that during those particular crises, the media was very instrumental in directing the public on what to do as a result of the information they were relying on their media platforms.

Furthermore, in situations of disasters and crises, and or such as the current COVID-19 pestilence, the public often gets difficulties in decision making especially because of the heavy situations that they might not be able to comprehend which leads them to constantly and increasingly depend on the media because they believe that the media will be able to digest the information and make it easy for them to make informed decisions on the prevailing crisis (Hagar, 2013).

Furthermore, during crises, people's trust in the media becomes vital to their dependency on the media and the effects that come out of that trust, which makes both the media and trust to be interrelated (Kiousis, 2011, Jackob, 2010, Tsfati, 2003). This revelation implies that the more a person starts to depend on a certain media for information, the more they will have higher levels 
of trust and vice-versa, although trust is particularly very important during crisis times (Bucher, 2002).

There are other studies (Hindman \& Coyle, 1999) that have been done on media dependency in times of crises and uncertainties, and results indicated that dependency on radio and television increased during the flood disaster at the time. This also affirms the notion where the theorists predict that the dependency on media is usually dependent on the media type. In addition, media exceeded interpersonal communication as a very important source of information during a volcano eruption where the public kept on relying on the media even when the information was unverifiable at the time (Dillman, and Ball-Rokeach, 1986). The discussions above continue to prove that the media is still an important factor in relaying important information to the public in situations of crises like the present COVID-19 pandemic.

\section{Dependency on Traditional Media in crises}

In the time of crises, traditional media especially television always interprets the situation for the public. Thus, Television becomes the audience's source of information because it is quick and relays it in real-time combined with both sound and motion pictures that resonate well with the audience (Adkisson, 2013). In addition, Adkisson's study also found out that, the participants rely more on television for information on situations convening weather crises.

Furthermore, in their study, Piotrowski and Armstrong (1998) found out that, most of the respondents preferred traditional media channels like the TV and radio for information seeking because they were effective tools of communication during the hurricane crisis. In addition, the participants also found that television information was more valued because it had a direct effect on them as a result of the sound and motion pictures it relays.

Greenberg, Hofschire, and Lachlan (2002) in their study observed the importance of media during crises and found out that, majority of the participants preferred a sound and motion picture relaying media for receiving information in times of disaster epidemic crises. This though may not be static because people's information-seeking behavior and the channels they want may vary depending on what motivates them to choose what they choose.

Media systems dependency theory posits that; TV is a suitable source of information during crises. Therefore, when the public feels threatened by the natural environment, they gain a high level of 
dependency on media like the television because it quickly places them at the scene of the crisis (Loges, 1994). Also, Hirshburg et al. (1986) argue that television media dependency increases during crises. However, although the traditional (TV and radio) news may not immediately reduce uncertainty in times of crises, the public usually perceives them as very vital sources of information for their decision-making. That's why, selecting traditional media as the ultimate source of information in times of crisis is not just a habit, but because it has some vital qualities, such as the inclusion of sound, text, and motion symbols that resonate quickly with the public in creating their assumptions and images about a prevailing crisis. This revelation, therefore, leads to the formation of hypothesis number one.

H1 There is a high level of dependency on traditional media as the public's source of information during the COVID-19 crisis in Malaysia.

\section{Dependency on New media during Crises}

With the emergence of new media platforms, several studies have been done linking them to promoting dialogues and solving intricate situations like crises in form of propagating information in a short time but in a viral manner and on a large scale (Kryvasheyeuet al., 2015). In addition, new media communication platforms can grant the user free access to propagating all sorts of information by expressing their feelings while sharing ideas about events happening in their environments (Basil, and Bocarnea, 2003).

Furthermore, Lee (2012) in his YouTube study about emotional expressions on the death of Michael Jackson found out that YouTube helped users to properly air out their emotions freely through anger and frustrations over the way Michael Jackson was being covered by the mainstream media. however, it also gave a platform to those who were exhibiting positive emotions like happiness relating to his music career and how it impacted massively on society. The social platform enabled users to comment, post, and share information related to the subject matter where millions of internet subscribers had an opportunity to see the positive and negative comments that users were attributing to Michael Jackson (Rainer et al., 2013). Therefore, in that situation of grief, the public was availed with an opportunity of seeing what was going on through YouTube user's comments and shares on the matter from all walks of life from the supporters of the legendary singer. This also means that users online can ably communicate with each other in the shortest period by sharing ideas on the crisis at a particular time. 
Coombs (2014) argues that new media have got a new style of communication that is viral which allows them to share information instantly with anyone they desire and at any time and it becomes the topic of the day. In a similar study, Thompson et al. (2017) found out that, social media platforms increased the flow of information relating to the school shooting as a result of parents' and student's postings on the internet. This implies that depending on new media may help those in dire situations or need of help in case of any emergent situations. It also confirms that such information will gain a more positive impact on the crisis at hand.

In the context of the current COVID-19, there have been numerous volumes of information related to the pandemic especially during its initial stages of the outbreak that even made the public start doubting the situation at hand. However, mass media played a very important role to educate the public on the dangers of the virus ad in some instances clarifying the possible miss information that might have been disseminated on the internet. Therefore, in times of crisis, social media may be relied on, and on the other hand, there is a need to screen the kind of information one receives from these platforms because some ties they may mislead the public regarding the same.

Therefore, in times of crisis, new technologies and communication platforms are not only used for communication seeking but also act as a vehicle for information sharing to those who might need it regarding any prevailing crisis at hand (Ishengoma, 2014). However, increased online communication during crises may be a result of its bigger consequences on an individual's wellbeing (Greenberg et al., 2002).

Worth to note, social media platforms have become a vital tool for crisis communication like in the present COVID-19 where government departments nowadays opt to use them to communicate with the masses because effective communication is very important during crises and the social media platforms seem very efficient in doing so and in the shortest period with even a guarantee of the information becoming viral (Simon et al., 2014).

Additionally, new ICT tools are better gadgets for engaging in recovery efforts during crises because they are instant and quick in message delivery and viral reach. That's why, in the majority of crisis studies, the majority of participants believe that they can be rescued very quickly, shortly after posting a request through social media (American Red Cross, 2010). That's why, some researchers have gone ahead to conclude that, the public prefers social media news than news on traditional media during crises because they communicate more with each other possibly through 
social media comments on posts than in traditional media that take some time to materialize (Stephens \& Malone 2009).

For instance, when government departments delay in providing relevant news regarding a particular event or crisis, social media becomes a solution for information flow (Sutton et al. 2018). Accordingly, it becomes more prominent since traditional media are banned from reporting incidents in which they can engage and report to the public freely without scrutiny (Mäkinen \& Kuira, 2018).

H2 There is a high level of dependency on online/social media as the public's source of information during the COVID-19 crisis in Malaysia.

\section{Media dependency and COVID-19}

The emergent of COVID-19 is like a crisis that demands stringent and specific measures because of its abruptness and uncertainty in terms of the threats it has created among the populace (Seeger, Sellnow, \& Ulmer, 2003). In such instances, people always are faced with situations of anxiety and panic as a result of the increased spread of the disease and the negative information around it, which calls for a neutral person to comfort them and in this case being the media (PEW Research Center, 2020). Some studies have concluded that people in controlled situations are always dependent on the media to know what is happening outside their controlled environments (Sarault, 2020). In this case, the media around the world have been circulating tones of COVID-19 related information to the public since its outbreak. For example, in the US, there was an increase in the dependency of the public on the major news media by 68\% in February and march of 2020, results of which confirm that the public was so much dependent on those news sites in the search for information related to the virus (Sarault, 2020).

The above discussions are highlighted well by the media dependency theory which posits that, during a disruption in the social lives of the people, there is a high and an unusual consumption of information and want to make sense out of the occurrence of the situation through what is displayed by the media in their production of social news because the media is always perceived to satisfy the needs of the people during such situations (Lowrey, 2004). Therefore, people always depend on the media to get information so that they can make sense out of their situation and form an opinion on what to do next (Mukkamala \& Beck, 2018 and Martinez-Rojas et al., 2018). This same 
has been happening during the outbreak of the pandemic where the public has been and is reliant on the media especially in terms of getting accurate information regarding the virus to reduce their panic and anxiety towards the virus (Taha, Matheson \& Anisman, 2014).

Similarly, Coombs (2020) argues that COVID1-9 has brought about specific demands in solving crises in communication especially dealing with furnishing the public with the rightful information concerning the virus so that people can make informed decisions. In addition, various researchers on media coverage in the COVID-19 era have found out that spreading the rightful information to the public can help in reducing panic and uncertainty among people (Charoensukmongkol \& Phungsoonthorn, 2020 and $\mathrm{Wu}$ et al., 2020a). Also, during a health-related threat like the present Pandemic, timely updates from trusted sources about the risk of getting the virus are critical. Without depending on such media organizations, public fears may be escalated, rumors increased, and people's stress levels are hiked.

Relatedly, certain discussions related to the pandemic have been done through social media especially during situations where the government takes longer to release vital information related to the virus. This prompts the public to be keen on what is happening regarding the pandemic, and they always find a lot of differing information on social media from the different participants (Gao et al., 2020). The deliberations on social media may increase rumors and or misinformation on the virus which may lead to the creation of what WHO termed as an infodemic, which speeds up the epidemic process (Kim et al., 2019; Zarocostas, 2020). This is all done because dependency on the new and old media can generate knowledge among the population related to the virus and crisis at hand (Lin, Xu, and Dam, 2021).

Wang et al. (2021) contend that the media is always getting information from the right sources like the government departments responsible for information dissemination, WHO, CDC, and other authorized agencies and screen it out to make sense to the public to whom they serve for their own decision making on issues related to COVID-19. For example, the authorities in Malaysia and other surrounding countries provide daily updates regarding COVID-19 through news conferences and releases for the proper improvement of the populace's awareness of the strategies the government is taking to prevent the spread of the virus (Bao et al., 2020). This revelation indicates that the media has a duty of disseminating the information they receive from their sources like the 
government to the public so that the people can become aware of the possible strategies and how to control themselves to prevent the spread of the corona virus. The public then becomes dependent on the media for any accurate information that they may get from the relevant health-related government institutions. This discussion leads to the formation of hypothesis three;

\section{Summary of the Hypotheses}

H1: There is a high level of dependency on traditional media as the public's source of information during the COVID-19 crisis in Malaysia.

H2: There is a high level of dependency on online/social media as the public's source of information during the COVID-19 crisis in Malaysia.

\section{RESULTS AND FINDINGS}

\section{Dependency on Traditional Media}

To answer hypothesis one which states that there is a high level of dependency on traditional media as a public source of information during COVID -19 in Malaysia, descriptive statistics were run on 1309 respondents to measure the frequency of dependency on traditional media among the Malaysian public during the COVID-19 crisis. The traditional media that was depended on to measure the public's media dependency on them were the Television, newspaper, and radio stations. The results of the test indicate that, overall, the majority (80.3\%) depend on television for at least four to seven days a week while looking for news regarding the COVID-19 pandemic. $14.6 \%$ also reported being depending on the television for news on the pandemic, although less than three times a week. In addition, a sizeable 5.1\% report not having any interest in depending on the television especially for news regarding the current pestilence.

The overall result here shows that a considerable majority depends on television for news during a crisis like the present COVID-19, a finding that is supported by Adkisson (2013) who intimated that, Television becomes the audience's source of information because it is quick and relays it in real-time combined with both sound and motion pictures that resonate well with the audience for them to make their informed decisions on their lives. Also, an example in Malaysia reveals that a considerable number of citizens reported being getting their COVID-19 information through news conferences and releases to properly improve their awareness of the strategies the government is 
taking to prevent the spread of the virus (Bao et al., 2020). In addition, Greenberg, Hofschire, and Lachlan (2002) also concluded that, in crises like the present pestilence, citizens always prefer sound and motion pictures in times of disasters and epidemic diseases for information seeking because it is effective and has verifiable information.

Regarding the newspaper, 37.0\% reported that they do not look for COVID-19 related information or news from the newspapers, whereas $23.3 \%$ noted to be relying on the newspapers within $4-5$ days a week, 20.4\% less than three days a week and lastly, 19.3\% indicated that they depend on the newspapers for COVId-19 information or news every day for seven days in a week. Here, there is a particular group of office employees and corporates that always prefer to read newspapers for information such as related to COVUD-19. This is also confirmed by people by scholars (Mukkamala \& Beck, 2018 and Martinez-Rojas et al., 2018) who contend that individuals especially the corporates and office workers always depend on the media to get information so that they can make sense out of their situation and form an opinion on what to do next. This they say, that newspapers are always trustable and always bears verified a d well-written accounts of information related to epidemics such as the current COVID-19, which is a long run helps them make informed decisions basing on the facts they read from the newspapers because they can also keep referring to them on a case by case basis.

The last medium that was depended on by Malaysians in the radio station. Here, the respondents report that six in ten $(63.6 \%)$ of the respondents depend on the radio for news and information regarding the COVID-19 pandemic. However, others 17.5\% reported depending on the medium of radio for information regarding COVID-19 for less than three days a week, while 18.9 did not at all listen to the radio station for such news and information related to the COVID-19 pandemic. This finding is supported by several scholars (Taha, Matheson \& Anisman, 2014) who intimate that radio stations provide timely information to the public for their consumption and possible reduction in their panic and anxiety towards the virus. Hirshburg et al. (1986) also argue that Radio and television dependency increases during an epidemic crisis like it has been happening in the current pandemic because the radio reaches in variety of places with its frequent and amplitude modulation signals where the internet takes long or even never reaches. The radio helps in spreading such information to distant areas and those who may choose to tune in from their vehicles and listen to the current affairs, COVID-19 pandemic being of them. 
Table 1 Frequency of dependency on traditional media

\begin{tabular}{|c|c|c|c|}
\hline Medium & Categories of Media Dependency & Frequency & Percentage \\
\hline \multirow{5}{*}{ Television } & No & 67 & 5.1 \\
\hline & $1-3$ days/week & 197 & 14.6 \\
\hline & $4-5$ days/week & 389 & 29.7 \\
\hline & 7 days/week & 662 & 50.6 \\
\hline & Total & 1309 & 100.0 \\
\hline \multirow{5}{*}{ Newspaper } & & 484 & 37.0 \\
\hline & $1-3$ days/week & 267 & 20.4 \\
\hline & $4-5$ days/week & 305 & 23.3 \\
\hline & 7 days/week & 253 & 19.3 \\
\hline & Total & 1309 & 100.0 \\
\hline \multirow{5}{*}{ Radio } & & 248 & 18.9 \\
\hline & $1-3$ days/week & 229 & 17.5 \\
\hline & $4-5$ days/week & 445 & 34.0 \\
\hline & 7 days/week & 387 & 29.6 \\
\hline & Total & 1309 & 100.0 \\
\hline
\end{tabular}

\section{Dependency on Online/Social media}

Hypothesis number two relates to the existence of a high level of dependency on online/social media as the public's source of information during the COVID-19 crisis in Malaysia. to answer this, SPSS was used specifically descriptive analyses to find out the frequency of usage and dependency on the online/social media platforms for information related to COVID-19 pandemic.

Firstly, more than half (57.7\%) of the respondents reported that they seek information related to COVID-19 seven days a week, $24.8 \%$ for four to five days in a week, $7.6 \%$ for less than three days a week, and lastly, 9.9\% did not get any COVID-19 information from the internet, making them not dependent on the internet.

Furthermore, on the respondent's dependency on online news portals, six in ten $(62.7 \%)$ of them often get information related to the pandemic daily. Others reported that in one to three days, they sometimes depend on online portals for Covid information (16.8\%). However, there is a $20.6 \%$ number of respondents who never depend on online portals for COVID-related information, but might be using the online portals for different things which might include playing games for fantasies as well as passing time. This makes them nondependent on such informative platforms that publish credible information relating to the virus. This is reinforced by Rainer et al. (2013) who in their study found out that, using social platforms for information during a crisis like the present COVID-19 pandemic enables users to comment, post, and share information related to the subject matter where millions of internet subscribers can get an opportunity to see the positive and 
negative comments that may help them in making their decisions. This in addition also helps them exchange ideas through comments in a short period.

Similarly, those who were dependent on Facebook seven days a week for COVID -19 related information are $51.3 \%$, four to five days a week are $27.9 \%$, one to 3 days a week are $7.9 \%$, and $13.3 \%$ of those that never depended on Facebook for COVID-19 related information. This finding is confirmed by the results of Coombs (2014) who deduced in his study that, new media platform has a viral gene in nature that helps drive the information in a speedy manner which allows them to share information instantly with anyone they desire and at any time, making it the topic of the day.

For Twitter, more than half $(56.6 \%)$ of the respondents reported that they do not use it for information related to COVID-19 at all, but, they were using it for other things like understanding social situations and other fantasies. However, some used Twitter at least seven times a week (19.5\%) for searching for information related to COVID-19, 12.4\% for four to five days a week, and lastly, those who depended on it for COVID-19 information in less than three days a week were 11.5\%. This result means that Twitter was not favorite for searching for COVID-19 related information to the respondents.

Furthermore, there were a seven in ten (71.7\%) number of respondents who depended on WhatsApp for COVID-related information for seven days a week daily. This is in line with the findings of Thompson et al. (2017) who found out that, social media platforms like WhatsApp increases the flow of information relating to the subject of interest as a result of constant postings of the issues on the internet. This confirms that such information gained through such means gains a more positive impact on the crisis at hand. Other respondents $(18.3 \%)$ were dependent on the medium of WhatsApp for four to five days in a week, $4.1 \%$ for one to three days a week, and $5.9 \%$ reported not have used the platform for information related to COVID -19 but rather other socially related issues. These findings also reveal that WhatsApp as a platform was the highest used platform in searching and receiving COVID-19 related information.

Lastly, the results of this test proved that one-third (38.6\%) of the respondents did not use Instagram for COVID-9 related information, but rather, they might have used it for other socially related activities like understanding their social lives and gaining friendships from other people. In addition, about one quarter (29.5\%) reported that they depended on covid-19 information got 
from Instagram for seven days a week, $17.0 \%$ for four to five days a week and $15.0 \%$ for one to three days per week.

Table 2 Frequency of dependency on online/social media

\begin{tabular}{|c|c|c|c|}
\hline Medium & Categories of Media Dependency & Frequency & Percentage \\
\hline \multirow{5}{*}{ The Internet } & No & 129 & 9.9 \\
\hline & $1-3$ days/week & 100 & 7.6 \\
\hline & $4-5$ days/week & 325 & 24.8 \\
\hline & 7 days/week & 755 & 57.7 \\
\hline & Total & 1309 & 100.0 \\
\hline \multirow{5}{*}{ Online Portal } & No & 269 & 20.6 \\
\hline & $1-3$ days/week & 220 & 16.8 \\
\hline & $4-5$ days/week & 365 & 27.9 \\
\hline & 7 days/week & 455 & 34.8 \\
\hline & Total & 1309 & 100.0 \\
\hline \multirow{5}{*}{ Facebook } & No & 174 & 13.3 \\
\hline & $1-3$ days/week & 103 & 7.9 \\
\hline & $4-5$ days/week & 361 & 27.6 \\
\hline & 7 days/week & 671 & 51.3 \\
\hline & Total & 1309 & 100.0 \\
\hline \multirow{5}{*}{ Twitter } & No & 741 & 56.6 \\
\hline & $1-3$ days/week & 151 & 11.5 \\
\hline & $4-5$ days/week & 162 & 12.4 \\
\hline & 7 days/week & 255 & 19.5 \\
\hline & Total & 1309 & 100.0 \\
\hline \multirow{5}{*}{ WhatsApp } & No & 77 & 5.9 \\
\hline & $1-3$ days/week & 54 & 4.1 \\
\hline & $4-5$ days/week & 239 & 18.3 \\
\hline & 7 days/week & 939 & 71.7 \\
\hline & Total & 1309 & 100.0 \\
\hline \multirow{5}{*}{ Instagram } & No & 505 & 38.6 \\
\hline & $1-3$ days/week & 196 & 15.0 \\
\hline & $4-5$ days/week & 222 & 17.0 \\
\hline & 7 days/week & 386 & 29.5 \\
\hline & Total & 1309 & 100.0 \\
\hline
\end{tabular}

\section{CONCLUSION}

Overall, the study employed 1309 respondents who reported on using and depending on several media platforms for information relating to the COVID-19 pandemic. Results indicate that, on average, the respondents depended on the new media platforms like the online portals, Facebook, WhatsApp, Twitter, and Instagram as their preferred platforms in searching and receiving COVID19 related information. The results are supported by Kryvasheyeuet al. (2015) who contend that depending on new media platforms for information during crises like the epidemic diseases leads 
to solving intricate situations in a short period, and may in a long run lead to the messages going viral, in addition to granting free access to propagating all kinds of information by expressing their feelings while sharing ideas about events happening in their environments. Therefore, online/social platforms are dominant in times of crises especially for information seeking and sharing, and because they are easily accessible to everyone who has a mobile gadget and access to the internet. Also, the results in the present study reveal that social media platforms were and still are a vital communication tool in crises like the present COVID-19 pandemic that requires quick gadgets in engaging in recovery efforts because of their viral reach. Therefore, all the hypotheses were done and supported by the results in a positive manner.

As for traditional media, the results indicate that on average, a considerable number of the respondents showed interest in seeking COVID-19 related information from the traditional media (television, newspaper, and radio) and thereby making them dependent on that information for their decision making. However, when compared to the two media approaches, the results reveal that new media still has an upper hand in quickly solving information-related issues during epidemic crises like the current COVD-19 pandemic.

Worth note though from the results is that a considerable number of respondents replied not having used any type of media (traditional and online/social media) for information related to COVID19. This could only mean that they have the platforms, but use them for understanding several other social engagements and fantasies to satisfy their needs and desires. 


\section{REFERENCES}

Adkisson, R. V. (2013). Policy convergence, state film-production incentives, and employment: A brief case study. Journal of Economic Issues, 47(2), 445-454.

Ball-Rokeach, S. J. \& DeFleur, M. L. (1976). A dependency model of mass-media effects. Communication Research, 3(1), pp. 3-21.

Ball-Rokeach, S. J. (1985). The origins of individual media-system dependency a sociological framework. Communication Research, 12(4), pp. 485-510.

Brown, W. J., Basil, M. D., \& Bocarnea, M. C. (2003). Social influence of an international celebrity: Responses to the death of Princess Diana. Journal of communication, 53(4), 587605.

Cambridge, Massachusetts, USA.

Coombs, W. T. (2014). Ongoing crisis communication: Planning, managing, and responding. Sage Publications.

Grant, A. E., \& Meadows, J. H. (Eds.). (2020). Communication technology update and fundamentals. Routledge.

Greenberg, B. S., Hofschire, L., \& Lachlan, K. (2002). Diffusion, media use, and interpersonal communication behaviors. Communication and Terrorism: Public and media responses to, $9(11), 3-16$.

Hagar, C. (2013). Crisis informatics: Perspectives of trust-is social media a mixed blessing? School of Information Student Research Journal, 2(2), 2.

Hindman, D. B., \& Coyle, K. (1999). Audience orientations to local radio coverage of a natural disaster. Journal of Radio Studies, 6(1), 8-26.

Hirschburg, P. L., Dillman, D. A., \& Ball-Rokeach, S. J. (1986). Media system dependency theory: Responses to the eruption of Mount St. Helens. Media, audience, and social structure, 117 126. http://dx.doi.org/10.1016/j.telpol.2014.12.003i.

Hu, B., \& Zhang, D. (2014). Channel selection and knowledge acquisition during the 2009 Beijing H1N1 flu crisis: A media system dependency theory perspective. Chinese Journal of Communication, 7(3), 299-318.

Jackob, N. G. E. (2010). No alternatives? The relationship between perceived media dependency, use of alternative information sources, and general trust in mass media. International Journal of Communication, 4, 18.

Khalifa, H., \& Khalifa, H. (2020). Media Dependency during COVID-19 Pandemic and Trust in Government: The Case of Bahrain. International Journal of Management, 11(11).

Kiousis, S. (2011). Agenda-setting and attitudes: exploring the impact of media salience on perceived salience and public attitude strength of us presidential candidates from 1984 to 2004. Journalism Studies, 12(3), 359-374. 
Kryvasheyeu, Y., Chen, H., Moro, E., Van Hentenryck, P., \& Cebrian, M. (2015). Performance of social network sensors during Hurricane Sandy. PLoS One, 10(2), e0117288.

Lee, C. S. (2012). Exploring emotional expressions on YouTube through the lens of media system dependency theory. New media \& society, 14(3), 457-475.

Li, X. (2014). Perceived channel efficiency and motivation and orientation of information seeking as predictors of media dependency. Telematics and Informatics, 31(4), 628-639.

Loges, W. E. (1994). Canaries in the coal mine: Perceptions of threat and media system dependency relations. Communication Research, 21(1), 5-23.

Loges, W. E. (1994). Canaries in the coal mine: Perceptions of threat and media system dependency relations. Communication Research, 21(1), 5-23.

Longstaff, P. (2005). Security, Resilience, and Communication in Unpredictable Environments Such as Terrorism, Natural Disasters, and Complex Technology, s.l: Center for Information Policy Research. Harvard University.

Longstaff, P.H. (2005). Security, resilience, and communication in unpredictable environments such as terrorism, natural disasters, and complex technology. Harvard University and the Center for Information Policy Research,

Lowrey, W. (2004). Media dependency during a large-scale social disruption: The case of September 11. Mass Communication \& Society, 7(3), 339-357.

Mäkinen, M., \& Wangu Kuira, M. (2008). Social media and post-election crisis in Kenya. The International Journal of Press/Politics, 13(3), 328-335.

Mitomo, H., Otsuka, T. \& Kimura, M. (2012). The Role of Media and ICT to Motivate People to Take Post-Quake Recovery Action: An Evidence of the "Pythagorean Effect". Bangkok, Thailand, ITS 2012 19th Biennial Conference, November 18-21, 2012.

Napoli, P. M. (2015). Social media and the public interest: Governance of news platforms in the realm of individual and algorithmic gatekeepers. Telecommunications Policy

Patwardhan, P., \& Yang, J. (2003). Internet dependency relations and online consumer behavior: a media system dependency theory perspective on why people shop, chat and read news online. Journal of interactive advertising, 3(2), 57-69.

Piotrowski, C., \& Armstrong, T. R. (1998). Mass media preferences in disaster: A study of Hurricane Danny. Social Behavior and Personality: an international journal, 26(4), 341345.

Rainer, K., Grubmüller, V., Pejic, I., Götsch, K., \& Leitner, P. (2013). Social media applications in crisis interaction. Systema: connecting matter, life, culture and technology, 1(1), 110127.

Robertson, J. T. Media Dependency During a Potential Terrorist Attack to the US Food and Fiber System. 
Stephens, K. K., \& Malone, P. C. (2009). If the organizations won't give us information...: The use of multiple new media for crisis technical translation and dialogue. Journal of public relations research, 21(2), 229-239.

Tai, Z., \& Sun, T. (2007). Media dependencies in a changing media environment: The case of the 2003 SARS epidemic in China. New media \& society, 9(6), 987-1009.

Thompson, B., Mazer, J. P., Payne, H. J., Jerome, A. M., Kirby, E. G., \& Pfohl, W. (2017). Social media and active shooter events: A school crisis communication challenge. Qualitative research reports in communication, 18(1), 8-17.

Tsfati, Y. (2003). Media skepticism and climate of opinion perception. International Journal of Public Opinion Research, 15(1), 65-82.

Bao, Y., Sun, Y., Meng, S., Shi, J., \& Lu, L. (2020). 2019-nCoV epidemic: address mental health care to empower society. The Lancet, 395(10224), e37-e38.

Charoensukmongkol, P., \& Phungsoonthorn, T. (2020). The Interaction Effect of Crisis Communication and Social Support on The Emotional Exhaustion of University Employees during the COVID-19 Crisis. International Journal of Business Communication, 2329488420953188.

Coombs, W. T. (2020). Public sector crises: realizations from covid-19 for crisis communication. Partecipazione e conflitto, 13(2), 990-1001.

Gao, J., Zheng, P., Jia, Y., Chen, H., Mao, Y., Chen, S., ... \& Dai, J. (2020). Mental health problems and social media exposure during COVID-19 outbreak. Plos one, 15(4), 1-10, e0231924.

Kim, L., Fast, S. M., \& Markuzon, N. (2019). Incorporating media data into a model of infectious disease transmission. PloS one, 14(2), e0197646.

Lin, C. A., Xu, X., \& Dam, L. (2021). Information Source Dependence, Presumed Media influence, risk knowledge, and vaccination intention. Atlantic Journal of Communication, 29(2), 53-64.

Lowrey, W. (2004). Media dependency during a large-scale social disruption: The case of September 11. Mass Communication \& Society, 7(3), 339-357.

Martinez-Rojas, M., del Carmen Pardo-Ferreira, M., \& Rubio-Romero, J. C. (2018). Twitter as a tool for the management and analysis of emergency situations: A systematic literature review. International Journal of Information Management, 43, 196-208.

Mukkamala, A., \& Beck, R. (2018). The role of social media for collective behavior development in response to natural disasters.

Pew Research Center. Available online: https:/www.pewsocialtrends.org/2020/03/30/mostamericans-saycoronavirus- ou (accessed on 8 May 2021).

Sarault, J. (2020). Understanding media consumption during the Coronavirus Pandemic. ComScore, Inc. (accessed on 8 May 2021). 
Seeger, M. W., Sellnow, T. L., \& Ulmer, R. R. (2003). Communication and organizational crisis. Greenwood Publishing Group.

Taha, S. A., Matheson, K., \& Anisman, H. (2014). H1N1 was not all that scary: Uncertainty and stressor appraisals predict anxiety related to a coming viral threat. Stress and health, 30(2), 149-157.

Wang, Y., Hao, H., \& Platt, L. S. (2021). Examining risk and crisis communications of government agencies and stakeholders during early stages of COVID-19 on Twitter. Computers in human behavior, 114, 106568.

Wu, A. W., Connors, C., \& Everly Jr, G. S. (2020). COVID-19: peer support and crisis communication strategies to promote institutional resilience.

Zarocostas, J. (2020). How to fight an infodemic. The lancet, 395(10225), 676.

All Answers Ltd. (November 2018). Media Dependency During Terrorist Attacks: Comparison of Traditional and Social Media Use. Retrieved from https://ukdiss.com/examples/mediadependency-during-terrorist-attacks.php?vref $=1$

Jiang, J., \& Ouyang, N. (2008). New media use during the 5/12 Sichuan earthquake: A case study of media dependency. Media Asia, 35(3), 148-151.

Ishengoma, F. R. (2014). Online social networks and terrorism 2.0 in developing countries. arXiv preprint arXiv:1410.0531. 